\title{
The Influence of Word-of-Mouth Marketing Strategy on Consumer Decisions to Use Land Transportation Services CV. Taxi Service 88 Kotamobagu
}

\author{
Agus Irianto Paputungan, Saldin Paputungan, Herry Mokoginta \\ Institute of Economic Science \\ Widya Darma Kotamobagu, North Sulawesi, Indonesia \\ DOI: 10.31364/SCIRJ/v9.i10.2021.P1021885 \\ http://dx.doi.org/10.31364/SCIRJ/v9.i10.2021.P1021885
}

\begin{abstract}
Word of Mouth is the act of consumers providing information to other consumers from one person to another (interpersonal), both brands, products and services. The purpose of this study was to determine the effect of word-of-mouth marketing strategy on consumer decisions in using transportation services on CV. Taxi Service 88 Kotamobagu. The research method used is a quantitative method. Data analysis techniques used, namely simple regression, simple correlation and hypothesis testing. The theory used is the opinion of experts regarding the notion of management, marketing, marketing management, promotion, communication and communication effectiveness, marketing communication, word of mouth, word of mouth marketing, indicators, services, service characteristics, consumer behavior, purchasing decision making, results The research shows that Word of mouth marketing variable and consumer decision variable in CV. Taxi Service 88 Kotamobagu there is an influence between the $\mathrm{X}$ variable on the $\mathrm{Y}$ variable. This is indicated by the positive calculation results and justified by hypothesis testing, where there is a unidirectional relationship / influence, between the variables of the influence of Word-of-mouth marketing (X) on consumer decisions on CV. Taxi Service 88 Kotamobagu. So the company is expected to further improve the quality of services. More focus on customer satisfaction. Maintain good name and quality to avoid negative word of mouth.
\end{abstract}

Keywords: Word Of Mouth, Marketing, Strategy

\section{INTRODUCTION}

The world of marketing has never been separated from what is called communication skills. Communication skills here mean that the ability of a salesperson is a representative of a company in running a business. Marketing is a business that does not require capital. However, it is necessary to know that everything that is done must have a skill to be able to carry out an activity in the field of business, so as in the world of marketing there is a science of ability that must be honed and continue to be studied, namely the science of communication. Word of mouth is the act of consumers providing information to other consumers from one person to another (interpersonal) both brands, products and services. Personal communication channels in the form of words or word of mouth can be an effective promotion method because they are generally conveyed from consumers by consumers and to consumers, so that satisfied consumers or customers can become a chain message received by many people.

The strength of this promotion lies in the persuasive method used to convince prospective passengers, when from the $\mathrm{CV}$. Taxi Service 88 Kotamobagu provides information that is able to answer questions that generate satisfaction, this passenger will be loyal, and will spread positive information to other prospective passengers, such as relatives, friends and neighbors. Word of mouth as a promotional medium is influential in getting passengers because the Word-of-mouth approach is carried out directly so as to provide a convincing picture of information and information that is spread will benefit passengers, CV. Taxi Service 88 . In the era of globalization, as it is today, the marketing paradigm has changed, from traditional product-oriented marketing has evolved to become customer-oriented where business people pay more attention to consumer wants and needs. Based on this, marketing activities must be planned in advance in accordance with the wishes, needs, and expectations of consumers. Marketers must analyze consumer buying behavior because the buyer's reaction to the company's marketing strategy greatly impacts the success of the company itself. Today's economic developments encourage competition between companies engaged in the same field, such as the transportation business

The transportation business has a marketing strategy that is always an interesting phenomenon to talk about, namely word of mouth, or commonly called word of mouth promotion. The most effective promotion is through word of mouth. Satisfied customers will be the spokesperson for the company's products more effectively and convincingly than any type of advertising. One of the taxi companies that is well known and always wins the competition for this type of business is a land transportation service company, CV. Taxi Service 88 Kotamobagu. The emergence of new transportation service companies as well as companies that already exist, opens opportunities for each transportation service company to compete in reaching the market. Competition from the many existing transportation service companies, makes them compete to be able to attract consumers by providing better services, in addition to the attractive physical condition of the transportation fleet, security, and safety of passengers, as well as all the facilities provided to consumers.

WWW.scirj.org

(C) 2021, Scientific Research Journal

http://dx.doi.org/10.31364/SCIRJ/v9.i10.2021.P1021885

This publication is licensed under Creative Commons Attribution CC BY. 
The company is trying to get something of more value from customers. Customers are considered, or can be used as a promotional tool for the company through what is provided by the company, as well as what is felt by consumers. Consumers or customers are considered to be able to tell what they feel in using these transportation services, both in positive and negative terms from the company's side to others. Even if what is felt by the consumer is a positive thing, it is not impossible that the consumer will recommend or promote the company indirectly to others, and vice versa. A decision-making process does not only end with the occurrence of a purchase transaction, but is also followed by a stage of post-purchase behavior (especially in broad decisionmaking). In this stage the consumer feels a certain level of satisfaction, or dissatisfaction which will influence subsequent behavior.

The decision to use services is a series of activities carried out by consumers in relation to their needs. Feeling satisfied or dissatisfied consumers after using the service will affect the repurchase and loyalty of customers. The decisions made by consumers in the use of services are influenced by the results of the knowledge obtained and various factors, so that the decision to use services is a complex matter because it includes various aspects. Components of service quality facilities are several factors that influence consumer considerations in deciding purchases. Therefore, providing quality service to consumers is a very important concern for the company. Good service affects consumer satisfaction which will have an impact on repeated purchases which means there will be an increase in sales.

Good service can create customer satisfaction and loyalty, and help keep the distance from competitors. Business performance is assessed in terms of service quality by customers, where businesses with high quality services manage to charge higher prices, grow faster, and generate higher profits. In marketing activities word of mouth is an activity that can generate publicity and information about the products and services of a company. Consumers carry out word of mouth activities to share ideas, opinions, and information with others about the products and services they buy or use. Through activities like this, consumers can find out the quality of a product or service in a workshop. Based on this background, the researchers are interested in conducting research with the title: "The Influence of Word of Mouth Marketing Strategy on Consumer Decisions to Use Land Transportation Services CV. Taxi Service 88 Kotamobagu”.

\section{RESEARCH METHODS}

This research uses quantitative methods. The population in this study were customers of CV. Taxi Service 88 Kotamobagu is obtained from the number of passengers per day Kotamobagu - Manado and Manado - Kotamobagu, with the number of departing fleets of 14 fleets multiplied by 30 working days, so that a population of 2940 people is obtained. To get a sample that can describe, and represent the population, the determination of the sample in this study used the formula of Slovin Umar (2007:108, as follows:
$\mathrm{N}$
$\mathrm{n}=$
$1+\mathrm{N} \mathrm{e}^{2}$
$\mathrm{n} \quad=\quad$ Sample Size
$\mathrm{N}=\quad$ Population Size
$\mathrm{e} \quad=\quad$ Percent, allowance for inaccuracy due to sampling errors that can still be tolerated.

From the total population with an inaccuracy leeway of $10 \%$, then by using the above formula, a sample of

2940

$\mathrm{n}=$

$$
96,71=\quad 97 \text { People } \quad 1+2940(0.1)^{2}
$$

The sampling technique used in this research is using the Random Sampling procedure, which is a sample selection process in which all members of the population have the same opportunity to be selected. While the method used is Simple Random Sampling, which is a sample selection method in which members of the population are selected one by one randomly (all have the same opportunity to be selected) where if they have been selected they cannot be exchanged again (Kountur, 2004:139).

Variable Definition and Measurement

1. Word of mouth Marketing is an activity, or behavior carried out by consumers by promoting the advantages and disadvantages of the company to other people, or potential customers and given the symbol Y. The indicators for word-of-mouth marketing questions are:

a) Often hear conversations with other people about transportation services, CV. Taxi Service 88 Kotamobagu

b) Often talk about transportation services CV. Taxi service 88 Kotamobagu to others

c) Recommend the use of transportation services CV. Taxi service 88 Kotamobagu

wWW.scirj.org

(C) 2021, Scientific Research Journal

http://dx.doi.org/10.31364/SCIRJ/v9.i10.2021.P1021885

This publication is licensed under Creative Commons Attribution CC BY. 
2. The dependent variable is the variable that is affected or the result, because of the independent variable. In this study, the dependent variable is consumer decisions, namely consumer decisions to use services due to word-of-mouth marketing and given the symbol Y. Indicator variables from consumer decisions are:

a) I use CV services. Taxi Service 88 Kotamobagu because you often hear conversations from friends/others

b) I use CV. Taxi service 88 Kotamobagu after discussing with others

c) I will always recommend the use of transportation services, CV. Taxi service 88 to others

These variables were measured using a Likert scale. Likert scale is a type of scale used to measure research variables (specific social phenomena), such as attitudes, opinions and social perceptions of a person, or a group of people. The Likert scale used in this study is a Likert Scale 1-5 with the following information:

1) Score 5 for the answer Strongly Agree

2) Score 4 for the answer Agree

3) Score 3 for the answer Disagree

4) Score 2 for the answer do not agree

5) Score 1 for the answer Strongly Disagre

The analysis technique used in this study is as follows: Simple Regression Analysis, this analysis is to determine the magnitude of the influence between variable $\mathrm{X}$ (word of mouth marketing) on variable $\mathrm{Y}$ (consumer decisions). The form of a simple regression equation according to Priyatno (2010.55) with the formula is:

$$
\begin{aligned}
& Y=a+b X \\
& X=\text { Variable word of mouth marketing } \\
& Y=\text { Consumer decision variable } \\
& a=\text { Constant } \\
& b=\text { Regression coefficient }
\end{aligned}
$$

for the values of $\mathrm{a}$ and $\mathrm{b}$ can be calculated through the following equation:

$$
\begin{array}{ll}
\mathrm{a}= & \Sigma \mathrm{Y}-\mathrm{b} \cdot \Sigma \mathrm{X} \\
\mathrm{b}=\quad \mathrm{n} \cdot \Sigma \mathrm{XY}-\frac{(\Sigma \mathrm{X})(\Sigma \mathrm{Y})}{\mathrm{n} \cdot \Sigma \mathrm{X}^{2}-(\Sigma \mathrm{X})^{2}}
\end{array}
$$

Simple Correlation Analysis, this analysis is to regulate the close relationship between variable $\mathrm{X}$ (word of mouth marketing), and variable Y (consumer decisions) using the formula according to Priyatno $(2010,16)$ as follows:

$$
r=\frac{n \cdot \sum x y-\left(\sum x\right)\left(\sum y\right)}{\sqrt{n} \cdot \sum x^{2}-\left(\sum x\right)^{2} x \sqrt{n} \cdot \sum y^{2}-\left(\sum y\right)^{2}}
$$

Where the result of the value of $r$ ranges from -1 through 0 to +1

$$
\begin{aligned}
& \text { If } r \quad=\quad \begin{array}{l}
0 \text { or close to } 0, \text { then the relationship between the two variables is very weak, or there is no relationship at } \\
\text { all. }
\end{array} \\
& \text { If } r \quad \begin{array}{l}
1 \text { or close to } 1, \text { then the relationship between the two variables is positive, or there is a very strong } \\
\text { relationship. }
\end{array} \\
& \text { If } r \quad-1 \text { or close to }-1, \text { then the relationship between the two variables is very strong negative. }
\end{aligned}
$$

Determinant Coefficient, based on the value of $\mathrm{r}$ above, the coefficient of determination will be obtained by squaring the value of $\mathrm{r}$. This coefficient of determination states how much variation there is in variable $\mathrm{Y}$ described in $\%$ of variables. Hypothesis testing, testing needs to be carried out, to find out whether there is an independent relationship between the two variables or not. Hypothesis testing uses the t-test formula, with the following formula (Shita and Algifari, 2007,100):

$$
t_{h i t}=\frac{\frac{r \sqrt{n}-2}{\sqrt{1}-r^{2}}}{{ }^{2}}
$$

$\mathrm{r}^{2}=$ Coefficient of determination, which is the number of data variables studied and is usually calculated in 
percent $(\%)$.

$2=$ Constant value of the degree of freedom of regression $(\mathrm{n}-2)$.

$1=$ Constant value percentage of the value of $100 \%$.

The relationship between Word $\mathrm{f}$ Mouth Marketing (X) and consumer decisions ( $\mathrm{Y}$ ) is as follows:

- $\mathrm{Ho}=\mathrm{P}=0$ (there is no relationship between $\mathrm{X}$ and $\mathrm{Y}$ ).

- $\mathrm{HA}=\mathrm{P} \neq 0$ (there is a relationship between $\mathrm{X}$ and $\mathrm{Y}$ ).

- With $\alpha=5 \%$.

- Degrees of freedom $n-2$

- The test criteria are:

Reject $\mathrm{H} 0$ : $\mathrm{t}$ count $>\mathrm{t}$ table $(\alpha / 2)$

Accept Ha : t count $<$ t table $(\alpha / 2)$

\section{DISCUSSION}

\subsection{The Influence of Word-of-Mouth Marketing Strategy on Consumer Decisions CV. Taxi Service 88 Kotamobagu}

To determine the effect of the Word-of-Mouth Marketing strategy on Consumer Decisions, CV. Taxi Service 88 Kotamobagu, is to use a simple regression analysis with the following formula:

$$
\mathrm{Y}=\mathrm{a}+\mathrm{bX}
$$

To obtain the values of a and $\mathrm{b}$ can use the following formula:

$$
\begin{aligned}
& \text { n . } \Sigma X Y-(\Sigma X)(\Sigma Y) \\
& \mathrm{b}= \\
& \text { n. } \Sigma \mathrm{X}^{2}-(\Sigma \mathrm{X})^{2} \\
& \text { (97) }(16.775)-(1.253)(1.286) \\
& \mathrm{b}=\text {. } \\
& \text { (97) }(16.499)-(1.253)^{2} \\
& =\quad-\frac{1.627 .175-1.611 .358}{1.600 .403-1.570 .009} \\
& 15.817 \\
& =\text {. } \\
& \begin{array}{r}
30.394 \\
-\quad 0.52
\end{array}
\end{aligned}
$$

Furthermore, the value of a is obtained by using the following formula: for the average $\mathrm{X}$ and $\mathrm{Y}$ values, namely:

$$
\begin{aligned}
& X=\underset{N}{\Sigma X}=\frac{1.253}{97}=12.92 \\
& Y=\sum_{N} \mathrm{Y}=\frac{1.286}{97}=\underline{13.26}
\end{aligned}
$$

so, for the value of a can be found:

$$
\begin{aligned}
\mathrm{a} & =13,26-0,52(12,92) \\
& =13,26-672 \\
& =6,54
\end{aligned}
$$

Thus, the results of the regression equation are as follows: $\mathrm{Y}=6,54+0,52 \mathrm{X}$

\subsection{Relationship between Word-of-Mouth Marketing Strategy and Consumer Decision CV. Taxi Service 88 Kotamobagu}

WWW.scirj.org

(C) 2021, Scientific Research Journal

http://dx.doi.org/10.31364/SCIRJ/v9.i10.2021.P1021885

This publication is licensed under Creative Commons Attribution CC BY. 
To find the relationship between Word-of-Mouth Marketing strategy on Consumer Decisions, CV. Taxi Service 88 Kotamobagu can use correlation coefficient analysis using the following formula:

$$
r=\frac{n \cdot \sum x y-\left(\sum x\right)\left(\sum y\right)}{\sqrt{n}_{n} \sum x^{2}-\left(\sum x\right)^{2} \bar{x} \sqrt{ }_{n} \cdot \sum y^{2}-\left(\sum y\right)^{2}}
$$

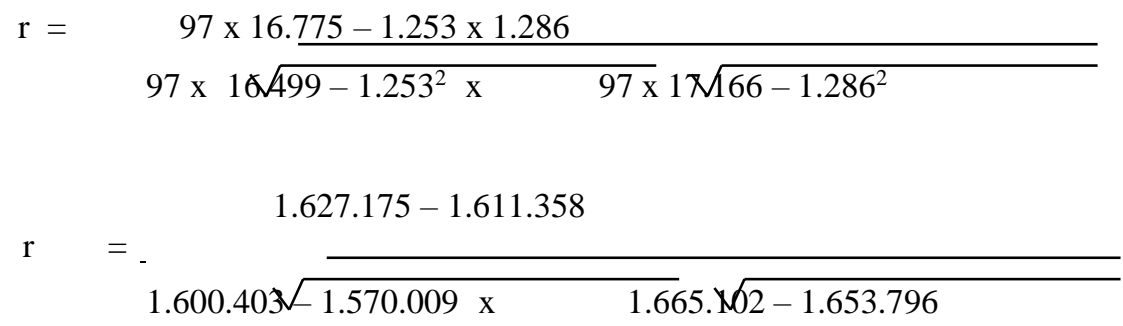

15.817

$\mathrm{r}=\operatorname{lil}_{174,34} \mathrm{x}^{\sqrt{106,33} \sqrt{ }}$

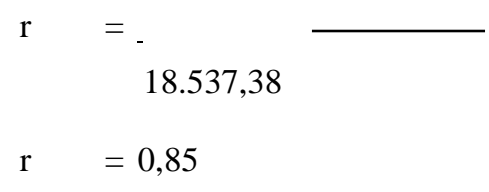

\subsection{Coefficient of Determination Between Word-of-Mouth Marketing Strategy Against Consumer Decisions CV. Taxi Service 88 Kotamobagu}

While the value of the coefficient of determination between the variables of Word-of-Mouth Marketing strategy on Consumer Decisions CV. Taxi Service 88 Kotamobagu, namely r2 $=0.73$.

\section{Hypothesis test}

This test is used to determine whether the hypothesis / suspicion of the influence and or relationship between the variables studied can be accepted or rejected. The hypothesis test that will be used here is the $t$ test (the student $t$ test), where the formula is

$$
t_{h i t}=\frac{\frac{r \sqrt{ } n}{\sqrt{ } 1-r^{2}}}{\frac{\sqrt{2}}{\sqrt{1}}}
$$

For analysis of the relationship between the influence of Word-of-Mouth Marketing strategy with Consumer Decisions CV. Taxi Service 88 Kotamobagu where the results obtained are known as:

$$
\begin{array}{ll}
\mathrm{r}=0,85 & \mathrm{n}=97 \\
\mathrm{r}^{2}=0,73 & 1=100 \%
\end{array}
$$

With the test criteria $\mathrm{t} \alpha=5 \%$ and $1 \%$, where is a critical value or error rate which states there is no relationship between $\mathrm{X}$ and $\mathrm{Y}$ variables:

If, $\mathrm{t}$ hit> $\mathrm{t} \alpha$ then reject Ho.

That is, the Ho hypothesis is that there is no relationship between the $\mathrm{X}$ variable and the $\mathrm{Y}$ variable. While the alternative alternative is the $\mathrm{H} 1$ hypothesis, namely there is a relationship between the $\mathrm{X}$ variable and the $\mathrm{Y}$ variable.

So t can be calculated:

\section{WWW.scirj.org}




$$
\begin{aligned}
& \text { thit }=\frac{0,85 \sqrt{97-2}}{\sqrt{1-0,73}} \\
& \text { thit }=\frac{0,85 \sqrt{95}}{\sqrt{0,272}} \\
& \text { thit }=\frac{0,85 \times 9,7468}{0,5215} \\
& \text { thit }=\frac{8,3164}{0,5215} \\
& \text { thit }=15,946 \\
& \text { dan }
\end{aligned}
$$

$$
\text { ttable } \propto, 5 \%=1,661
$$

From the results of the regression calculation, it turns out that there is a unidirectional effect between the variables of the Word-of-Mouth Marketing (X) strategy influence and the CV. Taxi Service 88 Kotamobagu (Y). Where the value of b is positive 0.52 which states that if the influence of word-of-mouth marketing strategy $(\mathrm{X})$ increases by 1 score, then customer satisfaction will increase by 0.52 or $52 \%$. Apart from the $b$ value above, it can also be seen that the result of a positive a value of 6.54 This shows that if there is no influence of the word-of-mouth marketing strategy $(\mathrm{X}=0)$, then the minimum consumer decision is 6.54 score.

The results of the correlation analysis show a positive correlation coefficient ( $\mathrm{r}=0.85)$, this relationship is very significant (very significant), which means that there is a very close relationship between the Word-of-Mouth Marketing strategy and the Consumer Decisions of CV. Taxi Service 88 Kotamobagu. While the value of the coefficient of determination between the variables of Word-of-Mouth Marketing strategy on Consumer Decisions CV. Taxi Service 88 Kotamobagu, i.e. $\mathrm{r} 2$ $=0.73$, it means that the relationship of the data studied between the variable $\mathrm{X}$ (Word of Mouth Marketing strategy) and the variable Y (Consumer Decision) is 73\%. The closeness of this relationship shows that the influence of the Word-of-Mouth Marketing strategy on the Consumer Decisions of CV. Taxi Service 88 Kotamobagu. of 0.73. In connection with that, the error / residual variable, namely the unknown / unresearched variable that also affects the data studied is $27 \%$. Thus, the relationship between the two variables studied is greater than the remaining variables. The result of the calculation of the hypothesis test is that $\mathrm{t}$ hit $=15.947$ is greater than $\mathrm{t}, 5 \%=1.6611$.

In the test criteria, namely:

$$
\begin{array}{ll}
- & \text { Reject } \mathrm{H} 0: \mathrm{t} \text { count }>\mathrm{t} \text { table }(\alpha / 2) \\
\text { - } & \text { Accept } \mathrm{Ha}: \mathrm{t} \text { count }<\mathrm{t} \text { table }(\alpha / 2)
\end{array}
$$

So, $\mathrm{H} 0$ is rejected which means that the hypothesis that there is a unidirectional relationship/influence between variable $\mathrm{X}$ (Word of Mouth Marketing strategy) and variable Y (Consumer Decision CV. Taxi Service 88 Kotamobagu) is acceptable (Ha). The criteria can be written:

"t hit $=15.947>$ t , $5 \%=1.6611$ so Ho is rejected." From the results of this hypothesis test, it shows that the Word-of-Mouth Marketing and Consumer Decisions strategy of CV. Taxi Service 88 Kotamobagu has a unidirectional significant relationship.

\section{CONCLUSION}

Word of mouth marketing variables and consumer decision variables on CV. Taxi Service 88 Kotamobagu there is an influence between the $\mathrm{X}$ variable on the $\mathrm{Y}$ variable. This is indicated by the positive calculation results, and justified by hypothesis testing, where there is a unidirectional relationship / influence between the variables of the influence of Word-ofmouth marketing (X) on consumer decisions on CV. Taxi Service 88 Kotamobagu. The company is expected to further improve the quality of services. More focus on customer satisfaction. Maintain good name and quality to avoid negative word of mouth. Companies are more accepting of suggestions and criticisms from consumers as consideration and input for developing product diversity to meet the increasingly diverse needs of consumers, and companies should pay more attention to post-sales services for consumers who want to use the services.

\section{REFERENCES}

Collin, P.H dan Ivanovic A. (2004). Dictionary of Marketing. Third edtion. Bloomsbury Publishing Plc, United States of America

Dwi Priyatno, 2010, Understand Statistical Analysis of Data With SPSS

Ekotama, Suryono. 2009. . Tricks for Cheap and Festive Promotions Yogyakarta: penerbit Cemerlang Publising.

WwW.scirj.org

(C) 2021, Scientific Research Journal

http://dx.doi.org/10.31364/SCIRJ/v9.i10.2021.P1021885

This publication is licensed under Creative Commons Attribution CC BY. 
Huryati, Ratih. 2005. Marketing mix and consumer loyalty. Bandung : Alfabeta.

Rangkuti, Freddy. 2009. Measuring the Effectiveness of Promotional Programs. PT. Gramedia Pustaka Utama. Jakarta.

Sernovitz, Andy, 2006, Word-of-mouth Marketing: How Smart Companies Get People Talking, Chicago: Kaplan Publishing.

Silverman, George,2001, The Secret of Word-Of-Mouth Marketing:How to trigger exponential sales through runaway word of mouth. AMACOM, United states of America

Setiadi, J. Nugroho. 2003. Consumer Behavior: Concepts and Implications for Marketing Strategy and Research. Pranada Media. Jakarta.

Shita Lusi Wardani dan Algifari, 2007, Projection Techniques For Business and Economics, BPFEYogyakarta

Sumardi, Marlin \& Melina. 2011. The power word of mouth marketing, Jakarta: penerbit PT. Gramedia Pustaka Utama

Umar, Husein. 2007, Research Methods For Business Thesis And Thesis, Jakarta: PT. Raja Grafindo Persada 